\title{
Evaluation of the Chemical Composition of Fish Species Captured in the lower Stretch of Itapecuru River, Maranhão, Brazil
}

\author{
Heliene Leite Ribeiro Porto ${ }^{1}$, Antonio Carlos Leal de Castro ${ }^{1}$, Victor Elias Mouchrek Filho ${ }^{2}$ \\ and Gandhi Rádis-Baptista ${ }^{3}$
}

\begin{abstract}
This study aimed to investigate the chemical composition of muscle tissues from seven species of fish, which were captured from the lower section of the Itapecuru river, comprising the municipalities of Santa Rita and Rosario and the coastal area of Golfão Maranhão during the period of June 2012 to May 2013. The species selected for the experiment were: Plagioscion squamosissimus, Geophagus surinamensis, Curimata sp., Prochilodus lacustris, Schizodon dissimilis, Ageneiosus ucayalensis and Hypostomus plecostomus, which showed significant abundance and high commercial value. Representative samples were collected without distinction of size and sex and only species with good organoleptic conditions were selected. Analysis of the muscle of each species was performed in triplicate to assess the moisture content, total fat, ash and energy value. The average results of proximate analysis revealed the following variations: moisture $73.7 \%$ to $79.2 \%$, total lipids $0.2 \%$ to $6.8 \%$, protein $18.6 \%$ to $23.0 \%$, ash $0.8 \%$ to $1.8 \%$ and the energy value of 77 to $136 \mathrm{kcal} / 100 \mathrm{~g}$. The species G. surinamensis showed a higher moisture content and ash and a lower energy value, indicating the highest mineral content between the studied species. The A. ucayalensis species had, on average, higher levels of total lipids and energy, while the P. lacustris species showed a higher percentage of proteins. The results confirm the importance of knowing the protein value of species that can serve different dietary purposes of local people.
\end{abstract}

Keywords - fish, Itapecuru river, nutritional quality, caloric value, Brazil.

\section{INTRODUCTION}

Human populations include fish as a main part of their daily diet, a fact that has become more relevant in developing countries, whose dietary pattern reveals a large dependency on staple foods, and fish is the main source, accounting in 2010, about $196 \%$ of animal protein consumption [1].

In addition to being recognized as a source of direct income of the Brazilian population, the fish is a very important food in the diet of individuals for its wealth of nutrients.

Vila Nova et al [2] pointed out that fish is of high nutritional value due to its high protein content, excellent quality of lipids

${ }^{1}$ Department of Oceanography and Limnology, Center for Health Sciences, Federal University of Maranhão, São Luís, Maranhão, Brazil.

${ }^{2}$ Department of Chemical Technology, Center for Science and Technology, Federal University of Maranhão, São Luís, Maranhão, Brazil.

${ }^{3}$ Laboratory of Biochemistry and Biotechnology, Institute of Marine Sciences, Federal University of Ceará, Fortaleza, CE, Brazil (omega 3 and 6 series) and low levels of total fat, saturated fats and cholesterol. It also incorporates high levels of polyunsaturated fatty acids, important for the promotion and maintenance of health and minerals like calcium, phosphorus, sodium, potassium and magnesium $[3,4,5]$.

According to the World Health Organization (WHO), the fish provides the healthiest animal protein and the Brazilians have arrived consuming $14.5 \mathrm{~kg}$ per inhabitant / year, exceeding the recommended minimum consumption of fish, which is $12 \mathrm{~kg}$ inhabitant / year or approximately $250 \mathrm{~g}$ of fish per week. Admittedly, the fish stands out for having in its composition high quality protein, retinol, vitamins $\mathrm{D}$ and $\mathrm{E}$, iodine and selenium. Evidence increasingly associates their consumption to greater brain development and learning in children, also improving eye health, and protection against cardiovascular disease and some cancers. The fats and fatty acids of fish are highly beneficial and difficult to obtain from other food sources [6].

The consumer acceptance of fishery products depends on various attributes of food quality. The most important attributes are food security, nutrition, taste, texture, color and appearance and suitability of raw materials for processing and preservation [7]. The relative importance of any of these features depends on the particular material and its intended use [8].

Information on the chemical and nutritional composition derived fishery products is important and badly needed for nutritionists, biologists and researchers who work with food, assisting in the formulation of diets, nutritional classification and supporting the food industries, conservation research and processing of fish.

Despite the diversity of fish and the commercial potential of many native species, Brazil is still very lacking in data related to its chemical composition and the effect of storage, especially under freezing in the constitution of fish flesh. Factors affecting the chemical composition of fish are numerous, and some are intrinsic in nature such as genetic, morphological and physiological factors as well as other related environmental quality of the area where they live.

Thus, research in this field of expertise, with detailed study of the nutritional composition of these regional fish through analytical techniques available, are of great importance because they provide essential information for the fish processing industry and intensive fish farming, as well as, and 
perhaps more importantly, for healthcare professionals in the nutritional management of fish, with a view to a proper dietary guidance, and seek real alternatives that can adequately meet the nutritional needs of individuals, and further stimulate consumption of regional species. Thus, in view of the importance food and the lack of information on the nutritional value of these regional fish, proceeded up the present study the chemical composition of the fish.

\section{MATERIAL AND METHODS}

\section{A. Material}

The data that form the basis for this study come from collections, quarterly carried out between the months of June / 2012 and May / 2013 in three different stations located in the lower stretch of the Itapecuru River between the ITALUÍS water catchment system and the mouth at the municipality of Rosario, Maranhão, Brasil. The species identification was made based on the work of: Eigenmanne Eigenmann [9] , Regan [10], Fowler [11], Fernández-Yépez [12], Britski [13], Mees [14], Isbrücker [15], Britski et al [16], Vari [17], Santos et al [18], Piorski et al [19, 20]. Taxonomic update was made by access to the Fishbase Project [21].

Of specimens captured, 7 species-individuals were selected for muscle tissue removal, using as criteria the capture volume and marketing potential. Samples considered had the best organoleptic conditions independent of the size of species and sex. The following taxa were selected: Plagioscion squamosissimus, Geophagus surinamensis, Curimata sp., Prochilodus lacustris, Schizodon dissimilis, Ageneiosus ucayalensis and Hypostomus plecostomus, and their morphometric measurements of total length $(\mathrm{cm})$, total weight (g) and identified sex were taken.

Some individuals of each species were filleted, disregarding sex, anatomical differences and physiological characteristics. Then to each sample was pulled out a portion of an average of $200 \mathrm{~g}$ of flesh from the lateromedial region (fillet-abdominal muscles), skinless and boneless representative of the edible part of each sample. Subsequently, samples were packed in plastic bags of polyethylene, properly identified and frozen at $-17^{\circ} \mathrm{C}$ until the time of analysis. Then analyses was carried out at laboratory of quality control of food and water in the Chemical Technology Department of the Federal University of Maranhão.

\section{B. Determining the Chemical Composition}

After homogenization, the following determinations were obtained using physico-chemical methods for food analysis of the Instituto Adolfo Lutz [22]:

- Humidity: determined by weight loss in oven set at $105^{\circ} \mathrm{C}$.

- Ash: obtained by igniting a known amount of the sample in furnace at $550^{\circ} \mathrm{C}$, to constant weight.

-Protein: determined by the Kjedhal method, which is used in the determination of total nitrogen. To convert the result into crude protein, the factor 6.25 was used.

-Total lipids: extracted using the Soxhlet method.

The total caloric value was calculated from the calorie corresponding coefficients for proteins and lipids, 4 and $9 \mathrm{kcal}$ / g respectively

\section{Statistical Analysis}

To compare the chemical and nutritional composition between species, we used a one-factor analysis of variance, after attaining the homogeneity of assumptions and normality of the data with the use of the Levene test. When the results of analysis of variance (ANOVA) indicated the presence of significant differences $(\mathrm{p}<0.05)$, the posteriori Tukey test was used to identify the differences between the means, adopting a 0.05 significance level. In cases where the ANOVA assumptions were not met, we used the non-parametric method of Kruskal-Wallis [23], accompanied by the nonparametric Mann-Whitney U test to compare possible differences between means.

Multivariate analysis using the ordination technique of principal components (PCA) was used to verify the association between the sampled species and the concentration of nutrients, based on the variance-covariance matrix.

The statistical evaluations were performed using the STATISTICA computer package, version 7.0 (Stat Soft Corp., USA) and Palaeontological Statistics (PAST), version 17.2 [24].

\section{RESULTS AND DISCUSSION}

\section{A. Proximate Analysis and Statistical Eveluation}

Table 1 shows the data of the chemical composition of the seven fish species ( $P$. squamosissimus, $G$. surinamensis, Curimata sp., P. lacustris, $S$. dissimilis, A. ucayalensis and $H$. plecostomus) and confirms the statement Maia et al [25] that although fish composition is well established as its predominant constituents, the ratio between them is very variable. 
TABLE I

CHEMICAL COMPOSITION AND CALORIC VALUE (MEAN \pm STANDARD DEVIATION) OF MUSCLE TISSUE FILLET OF SEVEN SPECIES OF FISH CAPTURED IN THE LOWER STRETCH OF THE RIVER ITAPECURU - MARANHÃO - BRAZIL.

\begin{tabular}{|c|c|c|c|c|c|}
\hline \multirow[t]{2}{*}{ Species } & $\begin{array}{l}\text { Humidity } \\
(\mathrm{g} / 100 \mathrm{~g})\end{array}$ & $\begin{array}{c}\text { Lipíd } \\
(\mathrm{g} / 100 \mathrm{~g})\end{array}$ & Proteíns (g/100g) & $\begin{array}{l}\text { *Ashes } \\
(\mathrm{g} / 100 \mathrm{~g})\end{array}$ & $\begin{array}{c}\text { *Energy value } \\
\text { (kcal/100g) }\end{array}$ \\
\hline & Média \pm Desvio & Média \pm Desvio & Média \pm Desvio & $\begin{array}{c}\text { Média } \pm \\
\text { Desvio }\end{array}$ & Média \pm Desvio \\
\hline P. squamosissimus ${ }^{\text {a }}$ & $77.6 \pm 1.04^{\mathrm{cf}}$ & $0.5 \pm 0.46^{b f}$ & $20.6 \pm 1.23^{\mathrm{cd}}$ & $1.3 \pm 0.26^{f}$ & $87 \pm 5.39^{\mathrm{cdf}}$ \\
\hline Curimata sp. ${ }^{\mathrm{b}}$ & $77.6 \pm 0.56^{\mathrm{cf}}$ & $1.4 \pm 0.44^{\text {defg }}$ & $20 \pm 0.38^{c}$ & $1.2 \pm 0.21^{\mathrm{f}}$ & $92 \pm 3.96^{\text {cdef }}$ \\
\hline P. lacustris $^{\mathrm{c}}$ & $75 \pm 2.16^{\operatorname{deg}}$ & $0.8 \pm 0.16^{\mathrm{efg}}$ & $23 \pm 1.41^{\text {def }}$ & $1.2 \pm 0.16^{\mathrm{f}}$ & $100 \pm 1.25^{\mathrm{defg}}$ \\
\hline G. surinamensis ${ }^{\mathrm{d}}$ & $79.2 \pm 1.57^{\mathrm{f}}$ & $0.4 \pm 0.16^{f}$ & $18.6 \pm 0.99^{g}$ & $1.8 \pm 0.81^{\mathrm{f}}$ & $77 \pm 4.60^{\mathrm{fg}}$ \\
\hline S. dissimilis ${ }^{\mathrm{e}}$ & $79 \pm 0.93^{f}$ & $0.2 \pm 0.07^{\mathrm{f}}$ & $19.7 \pm 0.65^{\mathrm{g}}$ & $1.1 \pm 0.13^{\mathrm{f}}$ & $81 \pm 2.24^{\mathrm{fg}}$ \\
\hline A. ucayalensis ${ }^{\mathrm{f}}$ & $73.7 \pm 0.78^{g}$ & $6.8 \pm 0.21^{g}$ & $19 \pm 0.67^{\mathrm{g}}$ & $0.8 \pm 0.05^{g}$ & $136 \pm 1.05^{\mathrm{g}}$ \\
\hline H. plecostomus ${ }^{\mathrm{g}}$ & $77.3 \pm 0.82$ & $0.2 \pm 0.05$ & $21.5 \pm 0.96$ & $1.1 \pm 0.11$ & $89 \pm 3.35$ \\
\hline
\end{tabular}

$\mathrm{a}, \mathrm{b}, \mathrm{c}, \mathrm{d}, \mathrm{e}, \mathrm{f}, \mathrm{g}=$ species identification that showed significant differences between them ( $\mathrm{p}<0.05)$, for each of the concentrations of chemical composition and calorific value. $*=$ Significant result for test of homogeneity of variances-application of non-parametric test of Kruskal-Wallis.

The results indicate that the average moisture content ranges from 77.3 to $79.2 \mathrm{~g} / 100 \mathrm{~g}$, and the highest value was found in species $G$. surinamensis and lowest in species $A$. ucayalensis (Table 1). Moisture as a major component of the edible portion of fish was also observed by Yeannes and Almandos [26] and Wang et al [27], confirmed water as the main component of the fish muscle, followed by protein and fat [28].

Although there is no scientific record with information about the nutritional value of fish species present in Itapecuru river, the chemical composition in muscle tissue of different species of fish surveyed in other freshwater environments showed variation of moisture content in the range of $64.0 \%$ to $90.0 \%$ [29, 30, 31, 32].

With regard to the concentration of lipid, the species investigated showed values ranging from 0.2 to $6.8 \mathrm{~g} / 100 \mathrm{~g}$, with a higher concentration in the muscle tissue of $A$. ucayalensis, then Curimata sp which showed a fat content of $1.4 \%$ of the total composition, while the other species showed even less significant values (Table 1 and Figure 2). Lourenço et al [33] reported lipid traits for the species $P$. squamosissimus captured by artisanal fishing on the Tocantins river in the state of Pará, lotic environment of nature, like the Itapecuru river, where $0.5 \%$ of content was found for the same species (Table 1).

These results were lower when compared to reports of Sanchez et al [29]; Guinazi et al [34]; Ramos Filho et al [35]; Caula et al [36]; Souza et al [37], all in search of the chemical composition of freshwater species. The relative superiority in the concentration of lipids in the studies cited above is probably due to the nature of the confined environment (dams, dam or breeding) suggesting a greater availability of nutrients. The protein content in the species $H$. plecostomus and $P$. lacustris showed values of $21.5 \%$ and $23 \%$, respectively, especially compared with other species caught in Itapecuru River, which ranged from 18.6 to $20.6 \%$ (Table 1). These values are presented above those reported by Sales and Sales (1990) for the species P. squamosissimus (18.1\%), Curimata sp (18\%) and Prochilodus cearensis (18.5\%), by Lourenço et al [33] for P. squamosissimus (15.6\%) on the Tocantins River in Pará and Caula et al [36] studied the chemical composition

of the species Prochilodus cearensis (18.7\%) in the state of Ceará.

These results show not only the assertion by Badolato et al [28], that protein is the second component with the highest contribution to the fish muscle, as well as the fishes investigated in the Itapecuru river are classified as rich protein content species.

Stansby [38] considers fish to be fatty or oily when it contains a content above $15 \%$ lipids, medium or semi-fat when between 5 and $15 \%$ and lean when its fat content is below $5 \%$. The same occurred with the protein, which Stansby and Olcott [39] consider low level when the fish present with less than $15 \%$ and high content, ranging from 15 to $20 \%$.

Thus, analyzing the mean values of lipid and protein samples investigated in this study, one can fit the species investigated in the class of lean and rich fish protein, except for the species A. ucayalensis. Furthermore, even considering the classification suggested by Stansby \& Olcott in Stansby \& Dassow [40], which fall under low fish lipids $(<5 \%)$ and high protein content $(15-20 \%)$ in category A, the samples analyzed from the Itapecuru river can be considered to be of excellent nutritional quality.

The results of the samples of this study agree, too, with a quotation from Stansby \& Olcott [39] in which the sum of the amounts of moisture and lipids in a study of proximate chemical composition in fish should be close to $80 \%$.

The average levels for ashes are marked in Table 1, revealing the species $A$. ucayalensis with the lowest ash content $(0.8 \%)$ and $G$. surinamensis signaling species with the highest content (1.8\%). The other species presented homogeneity as the average ash content, ranging from 1.1 to $1.3 \%$.

Aguiar [41] found, for Amazon, ash content of $1.0 \%$ to Schizodon sp and Prochilodus nigricans, $1.2 \%$ for Curimata $\mathrm{sp}$, all within the levels now presented, and from $1.8 \%$ to Plagioscion $\mathrm{sp}$, which is consistent with the high ash content found in this study for the species $G$. surinamensis but much higher than that found for $P$. squamosissimus and also the Plagioscion genre.

The other findings were compatible also with those reported by other authors such as Sales and Sales [42] also for 
P.squamosissimus and Curimata sp species (both $1.5 \%$ ); Sanchez et al [29] and Lourenço et al [33] $1.12 \%$ and $1.1 \%$ respectively for the species $P$. squamosissimus; and even in reports of Guinazi et al [34] studying freshwater species of Zona da Mata in the state of Minas Gerais; Ramos Filho et al [35] for species in the Pantanal region of Mato Grosso do Sul; Caula et al [36] reported ash content of freshwater species in the state of Ceará, including the Prochilodus cearensis species $(0.8 \%)$; and Souza et al [37] reported ash content of the species Schizodon fasciatum $(0.3 \%)$ in the Amazon.

The total content of nutrients such as calcium, potassium, sodium, magnesium, iron, copper, cobalt, aluminum, sulfate, chloride, silicate, phosphate and others is indicated by ash content, and overall ash content in fish varies between 1 to $2 \%$ of the total chemical composition, which is strongly influenced by the type of food species [43]. Thus, on the premise of these studies, G. surinamensis species showed higher ash content, indicating a higher mineral content.

Protein and ash contents below the range observed in this study were found by Maia et al [25] and UNICAMP [44] for species Prochilodus cearensis and P. squamosissimus, respectively, proving once again that the levels of lipids and moisture reported were superior for both studies.

As for caloric value, they have shown the species $S$. dissimilis, P. squamosissimus, H. plecostomus, Curimata $\mathrm{sp}$ and $P$. lacustris with average values between 81-100 kcal / $100 \mathrm{~g}$ weight, except getting to the species G. surinamensis 77 kcal and the species A. ucayalensis whch presented the maximum of $136 \mathrm{kcal} / 100 \mathrm{~g}$, the latter being the species with the highest content of lipids, among those studied.

Aguiar [41] analyzing the chemical composition of the fruits, vegetables and fish from the Amazon, reported calorific value of $89 \mathrm{kcal} / 100 \mathrm{~g}$ for the genre Plagioscion, very close to that found in this study for P. squamosissimus species which was $87 \mathrm{kcal} \mathrm{/} \mathrm{100g} \mathrm{(Table} \mathrm{1).} \mathrm{Already,} \mathrm{Caula} \mathrm{et} \mathrm{al} \mathrm{[36]}$ reported caloric value of $108 \mathrm{kcal} / 100 \mathrm{~g}$ to Prochilodus cearensis also very close to that found in this study for the species P. lacustris which was $100 \mathrm{kcal} / 100 \mathrm{~g}$ (Table 1).

Sales and Sales [42] obtained energy values for $P$. squamosissimus (109 kcal / $100 \mathrm{~g}$ ) and Prochilodus cearensis and Curimata sp (185 kcal / 100g both), in ponds and Souza et al [37] reported for the species Schizodon fasciatum, in Amazon waters, energy value of around $125.43 \mathrm{kcal} / 100 \mathrm{~g}$, so it's all much higher, compared to the values found in this study for P. squamosissimus (87 kcal / 100g), Curimata sp (92 kcal / $100 \mathrm{~g})$, P. lacustris (100kcal / 100g) and S. dissimilis (81 kcal / $100 \mathrm{~g})$, this difference in results are probably associated with the nature of the investigated environment, confirming what Stansby [38] postulates when he states that the chemical composition does not vary only from species to species, but also between individuals of the same species, and Visentainer et al [45] stating that the analytical data greatly vary according to the age, sex, diet, genetics, type and time of nesting, the productive stage, size, migration, and season as well as environmental factors associated with variations in fish habitat.

None of the seven species presented levels of carbohydrates, evaluated by the difference of the levels obtained from $100 \%$.

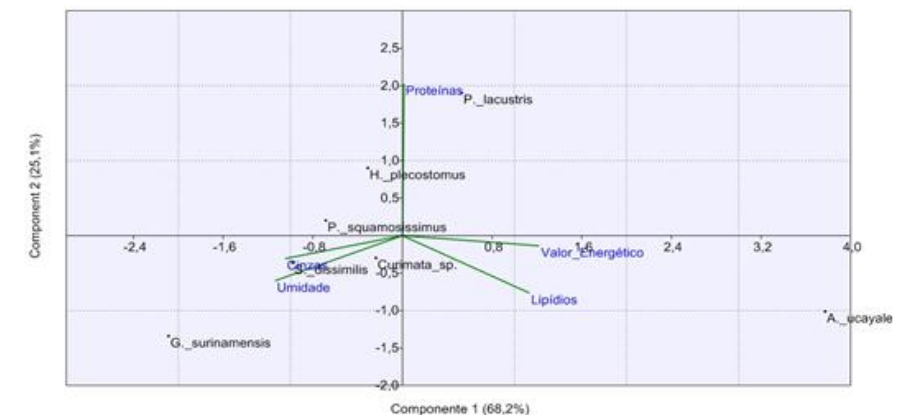

Fig. 1: Resultant factorial Plan of Principal Component Analysis of the chemical composition of species caught in the lower stretch of the Itapecuru river.

Comparison of chemical composition and nutritional values among the species investigated showed significant differences (p $0.05<$ ) between Ageneiosus ucayalensis species group consisting of: $P$. squamosissimus, Curimata sp, $G$. surinamensis and $S$. dissimilis, which were statistically similar in relation to moisture levels, lipids and proteins.

Regarding the multivariate analysis, it was observed that the $P$. lacustris species was associated with protein values through a direct and positive correlation, while the species $G$. surinamensis and A. ucayalensis, correlated negatively with the moisture content and lipids, respectively. The two main components of the analysis accounted for $93.3 \%$ of the total variability of the data indicating that the data set may be reduced and explained in two dimensions (Figure 2).

\section{CONCLUSION}

Humidity was the main component (73.0 to $81.5 \%$ ) of the fish muscle investigated, followed by protein representing the second component with the highest contribution. The Species Plagioscion squamosissimus, Geophagus surinamensis, Curimata sp, Prochilodus lacustris, Schizodon dissimilis and Hypostomus plecostomus based on literature records were classified in category A - lean, while Ageneiosus ucayalensis species was classified in category B - semi-fat species, presenting the latter as a good source of lipids. All species investigated were classified as rich protein content species, showing that they are good sources of protein, especially for Prochilodus lacustris species. The species Geophagus surinamensis showed higher ash content indicating greater content of minerals. From the nutritional point of view, species were found with different characteristics in the same environment, such as high protein content and low calorific value, such as Geophagus surinamensis, Schizodon dissimilis, Plagioscion squamosissimus, Hypostomus plecostomus and Curimata sp.., and others with high content of protein and energy value from $100 \mathrm{kcal} / 100 \mathrm{~g}$ as was the case of the species Prochilodus lacustris and Ageneiosus ucayalensis. The species reported in this study are presented as high-quality food, and may serve different dietary purposes for the local population.

\section{REFERENCES}

[1] FAO (Food and Agriculture Organization of the United Nations) .The State of World Fisheries and Aquaculture. Rome. 223 p. 2014. Available in: http://www.fao.org/3/a-i3720e.pdf > Accessed: jul. 23, 2015. 
[2] Vila Nova, Cândida M. Vieira Maia; Godoy, Helena Texeira; Aldrigue, Mauro Luiz. Composição Química, Teor de Colesterol e Caracterização de Lipídeos Totais de Tilápia (Oreochromisniloticus) e Pargo (Lutjanuspurpureus). Ciênc. e Tecnol. Aliment, Campinas, v.25, n.3, p.430-436. 2005 .

http://dx.doi.org/10.1590/S0101-20612005000300007

[3] Chandrashekar, K.; Deosthale, Y.G. Proximate composition, amino acid, mineral, and trace element content of the edible muscle of 20 Indian fish species. J. Food Compos. Anal., San Diego, vol. 6, no. 2, p. 195-200, 1993.

[4] Ismail, A.; Ikram, E.H.K. Effects of cooking practices (boiling and frying) on the protein and amino acids contents of four selected fishes. Nutr. Food Sci., Charlton v. 34, no. 2, p. 54-59, 2004

[5] Harris, W.S. Extending the Cardiovascular Benefits of Omega-3 Fatty Acids. Curr. Atherosclerosis Reports, Philadelphia, v. 7, p. 375-380, 2005 .

http://dx.doi.org/10.1007/s11883-005-0050-0

[6] FAO (Food and Agriculture Organization of the United Nations).The State of Food and Agriculture.Food systems for better nutrition. Pomegranate. 114p. 2013. Available at: http://www.fao.org/docrep/018/i3300e/i3300e.pdf > Accessed on aug 10, 2015.

[7] Cunha, Christiano França da; Spers, Eduardo Eugenio. A Percepção dos Consumidores Sobre Atributos de Origem, Sustentabilidade e Segurança em um Varejo Supermercadista. CLAV-CAPES / FAPESP / FGV. P 13, 2010.

[8] Haard, N. F. Technological aspects of extending prime quality of sea foods: a review. J. Aquatic Food Product Technol, 1, p 9-27, 1992. http://dx.doi.org/10.1300/J030v01n03_03

[9] Eigenmann, C.H; Eignmann, R.S. A revision of the South American Nematognathi or cat - fishes. Occasional Papers of the California Academy of Sciences, San Francisco, 1: 1-508. 1890.

[10] Regan, C.T.A. Monograf of the fishes of the family Loricariidae. Trans. Zool. Soc. London, 17 (3): 191-350, p. 9-21. 1904.

[11] Fowler, H.W. A collection of freshwater fishes Obtained in Eastern Brazil by Dr. Rodolpho von Ihering. Proc. Acad. Nat. Sci. Phila., 93: 123-199. 1941.

[12] Fernandez-Yépez, A. F. Contribucion al conocimento Doradidae de la familia en Venezuela. Bull. Inst. Oceanog., Univ. East. vol. 7, paragraph 1, p.7-72, figs., 36.1968.

[13] Britski, H.A. Peixes de água doce do Estado de São Paulo- Sistemática, p. 79-108. In Poluição e Piscicultura : notas sobre poluição, ictiologia e piscicultura, 216 pp. Com. Int. Basin Paraná-Uruguay and Fac. Public Health, USP, São Paulo. 1972.

[14] Mees, GF The Auchenipteridae and Pimelodidaeof Suriname (Pisces, Nematognathi), Zool. Verhandl. Leiden, 132: 1-256. 1974.

[15] Isbrücker, I.J.H. Descriptions preliminares de nouveaux taxa de le famille des Loricariidae. Revue Francaise d'aquariologie herpetologie, 5 (4): 86-116. 1979.

[16] Britski, H.A.; Sato, Y.; Pink, A.B.S. Manual de identificação de peixes da região de Três Marias: com chaves de Deputados identificação para os peixes da Bacia do São Francisco - 3 revised edition by the authors. Brasília: Câmara dos, tives, Publicações- Coordination CODEVASF, Division of Fish Farming and Fish, 1988.

[17] Vari, R.P. The Curimatidae the lowland Neotropical fish family (Pisces: Characiformes); distribution, endemism, phylogenetic and biogeography. In: Vanzolin, P.Z.; Heyer, W. R. Proceedings of the workshop on neotropical distribution patterns. Rio de Janeiro: Brazilian Academy of Sciences. 488 p. 1988.

[18] Santos, G.M.; Mérona, B.; Juras, A.A.; Jégu, M. Peixes do baixo rio Tocantins: 20 anos depois da Usina Hidrelétrica Tucuruí. Eletronorte. 216p. 2004.

[19] Piorski, N.M.; Castro, A.C.L.; Pereira, L.G.; Muniz, M.E.L. Ictiofauna do trecho inferior do rio Itapecuru, Nordeste do Brasil. Boletim do Laboratório de Hidrobiologia, 11: 15-24. 1998.

[20] Piorski, N.M.; Castro, A.C.L.; Sousa-Neto, A.M. Ichtyofauna from the Cerrado of the southern Maranhão. Pp. 197-212. In: L. Barreto (Eds.). North Cerrado of Brazil. Pelotas, USEB, 378P. 2007.

[21] Froese, R .; Pauly, D. Editors. FishBase. World Wide Web electronic publication, www.fishbase.org, version (10/2015) 2015.

[22] IAL (Instituto Adolfo Lutz). Métodos Físico-Químicos para Análise de Alimentos. Ed. IV. 1st. ed. Digital. São Paulo, SP: NIT / IAL, 1020 p,
2008 Available at: http://www.crq4.org.br/sms/files/file/analisedealimentosial_2008.pdf > Accessed on oct 11, 2015.

[23] Conover, William Jay. Practical Nonparametric Statistics. New Jersey: John Wiley \& Sons, p 584. 1990.

[24] Hammer, Øyvind; Harper, David A.T. ; Ryan, Paul D. Past: Paleontological statistics package software for education and data analysis. Palaeontologia Electronica 4 (1): p 9, 2001. Available at: http://palaeo-electronica.org/2001_1/past/past.pdf > Accessed on nov 29, 2015.

[25] Maia, Everardo Lima; Oliveira, Claudia C.S de; Santiago, André P.; Cunha, Francisca E.A; Holanda, Francisco C.A.F .; Sousa, Janaina A. A. Composição química e classes de lipídios em peixe de água doce curimatã comum, Prochilodus cearensis. Rev. Cienc. Tecnol. Aliment., V. 19 , no. 3, p. 433-437, 1999. http://dx.doi.org/10.1590/S0101-20611999000300025

[26] Yeannes, Maria Isabel.; Almandos, Maria Elsa. Estimation of fish proximate composition starting from water content. J. Food Compos. Anal., San Diego, vol. 16, p. 81-92, 2003.

[27] Wang, Yong; Liu, Yong-Jian; Tian, Li-Xia; Xiao, Wei Ping. Effects of dietary carbohydrate level on growth and body composition of juvenile tilapia, Oreochromisniloticus x O. aureus. Aquaculture Res., Oxford, vol. 36, p. 1408-1413, 2005.

[28] Badolato, E.S.G .; Oak, J.B.; Mello, M.R.P.; Tavares, M .; Campos, N.C .; Aued-Pimentel, S .; Moral, C. Composição centesimal, de ácidos graxos e valor calórico de cinco espécies de peixes marinhos nas diferentes estações do ano. Rev. Inst. Adolfo Lutz, São Paulo, v. 54, no. 1, p. 27-35, 1994

[29] Sanchez, Luiz; Gomes, Maria Isabel; Sase, Luciene Eiko. Armazenamento da pescada do piaú, Plagioscion squamosissimus (Hechel, 1840), resfriadas. I. Evolução da Composição química e alguns indicadores de frescor. Alim. Nutr. São Paulo, 2: 73-82.1990.

[30] Hart, F. L; Fischer, HJ Análisis modeno de los alimentos. Zaragoza, Acribia, cap. 10, p.249, 1997

[31] Andrade, G.Q; Bispo, E.S.; Druzian, J.I. Avaliação da qualidade nutricional em espécies de pescado mais produzidas no Estado da Bahia. Ciênc. Tecnol. Aliment., Campinas,v. 29, n. 4, p: 721-26, 2009.

[32] [32] Spitz, Jérome; Mourocq, Emeline; Schoen, Valérie; Ridoux, Vincent. Proximate composition and energy content of forage species from the Bay of Biscay: high- or low-quality food? ICES J. Mar. Sci., Oxford, vol. 67, no. 5, p. 909-915, 2010.

[33] Lourenço, Lúcia Fátima Henriques; Fernandes, Gleuba Maria Lacerda; Cintra, Israel Hidenburgo Aniceto. Características físicas, químicas e microbiológicas da pescada-branca Plagioscion squamosissimus (Heckel) salgada e seca em secador solar. Bol.Téc.Cient. CEPNOR Belém, v.1, n.1, p.135-144, 2001

[34] Guinazi, Michele; Moreira, Ana Paula Boroni; Salaro, Ana Lucia; Castro, Fátima Aparecida Ferreira; Danalto, Mirela; Pinheiro-Sant'Ana, Helena Maria. Acta Sci. Technol. Maringá, v. 28n. 2, p. 119-124, 2006.

[35] Ramos Filho, Manoel Mendes; Ramos, Maria Isabel Lima; Hiane, Priscila Aiko; Souza, Elizabeth Maria Talá de. Perfil lipídico de quarto espécies de peixes da região pantaneira de Mato Grosso do Sul. Ciênc. Tecnol. Aliment. Vol.28, no.2, Campinas, 2008.

[36] Caula, Francisco Charles Barros; Oliveira, Maria Petronília de; Maia, Everardo Lima. Teor de colesterol e composição centesimal de algumas espécies de peixes do estado do Ceará. Ciênc.Tecnol.Aliment., V. 28, no. $4,2008$.

[37] Souza, F. das Chagas do Amaral; Jesus, R. Souza de; Duncan, W.L.P.; Aguiar, J.P.L. Efeito do congelamento na composição química e perfil de aminoácidos da carne mecanicamente separada de peixes amazônicos. Rev. Pan-Amaz. Saude. Ananindeua, v.4, n.1, 2013.

[38] Stansby, Maurice Earl. Proximate Composition of Fish. FAO International Conference on Fish.In:Nutrition, Paper No. R / II, 1, 14 p. Washington, D.C., U.S.A., 1961.

[39] Stansby, Maurice Earl; Olcott, H.E. Technologia de la industria pesquera. Zaragoza: Acribia. p 391-400, 1968.

[40] Universidade de Campinas. Center for Studies and Research in Food NEPA.Tabela Brasileira de Composição de Alimentos. Version II. 2. ed. Campinas, SP. 114 p. 2006. Available at: http://www.unicamp.br/nepa/taco/contar/taco_versao2.pdf > Accessed on dec 29, 2015. Stansby, Maurice Earl; Olcott, H.E. Composición del 
pescado. In: Stansby, M.E.; Dassow, J.A. Tecnologia de la industria pesquera. Zaragoza: Acribia. p. 391-402, 1967.

[41] Aguiar, Jaime Paiva Lopes. Tabela de composição de alimentos da Amazônia. Acta Amazônica. 26 (1/2), pp 121- 126,1996. http://dx.doi.org/10.1590/1809-43921996261126

[42] Sales, Ronaldo de Oliveira; Sales, Armenia Maria. Estudo da composição química e rendimento de dez espécies de pescado de água doce de interesse comercial nos açudes do nordeste brasileiro. Ciên. Agron. Fortaleza, 21 (1/2), p 27-30, 1990.

[43] Viana, Z.C.V. Silva, E; Fernandes, G.B.; Santos, V.L.C.S. Composição centesimal em músculo de peixes no litoral do estado da Bahia/Brasil. Rev. Ciênc. Méd. Salvador, v.12, n.2, p.157-162, 2013.

[44] UNICAMP (Universidade de Campinas). Center for Studies and Research in Food - NEPA.Tabela Brasileira de Composição de Alimentos. Version II. 2. ed. Campinas, SP. 114 p. 2006.

[45] Visentainer, Jesuí Vergílio; Saldanha, Tatiana; Bragagnolo, Neura; Franco, Maria Regina Bueno. Relação entre teores de colesterol em filés de tilápias e níveis de óleo de linhaça na ração. Cienc. Tecnol. Alim. v. 25, n.2, p.310-314, 2005.

http://dx.doi.org/10.1590/S0101-20612005000200022 